\title{
Physical and chemical characteristics and productivity of persimmons (Diospyros kaki L.) cultivated in the Brazilian savannah
}

\author{
Lucas Marquezan Nascimento ${ }^{1}$, Lismaíra Gonçalves Caixeta Garcia ${ }^{1}$, Toshio Ogata $^{2}$, Daniel Cardoso \\ Brandão ${ }^{1}$, Carlos de Melo e Silva-Neto ${ }^{*}{ }^{3}$, Alexsander Seleguini ${ }^{1}$
}

${ }^{1}$ School of Agronomy, Federal University of Goiás, Goiânia, Goiás, Brazil

${ }^{2}$ EMATER, Anápolis, Goiás, Brazil

${ }^{3}$ Federal Institute of Education, Science and Technology of Goiás, City of Goiás, Goiás, Brazil

\section{*Corresponding author: carloskoa@gmail.com.}

\begin{abstract}
The Brazilian production of persimmon expanded in recent years, mainly due to the high productivity of the culture. The persimmon fruit is originally from subtropical climate. However, new cultivation areas in tropical regions seem promising, especially altitude regions in the Brazilian savannah. In this context, the objective of this study was to assess production, productivity and fruit quality components of three cultivars of persimmon cultivated in tropical regions. The persimmon cultivars Pomelo, Guiombo and Rama Forte were evaluated in regards to the physical and chemical characteristics of fruits and productivity in two harvest seasons (190 days after pruning and 220 days after pruning). Fruits were obtained from twelve-year-old trees cultivated at the Rural Experimental Station of Anápolis - GO, planted at a spacing of $7 \mathrm{~m} \times 5 \mathrm{~m}$ and grafted on common persimmon (Diospyros kaki L.) trees. The cultivars showed reliable levels of productivity, especially Pomelo and Giombo. The cultivar Giombo was the most productive in the region with an average yield of 545 fruits per plant. However, the Giombo fruit had reduced mass $(127 \mathrm{~g})$, and were smaller compared to the other evaluated cultivars. Pomelo fruits have higher average fresh mass $(224 \mathrm{~g})$, even without standing out with maximum yield. The highest yields were obtained for Giombo and Pomelo cultivars (13.25 and 19.27 ton/ha, respectively). Harvest time influences fruit parameters. The fruit harvested 190 days after pruning exhibited higher SS contents and lower acidity when compared with the other fruit harvested 220 days after pruning, regardless of the cultivar. The fruits on the plant darken over time. The Pomelo cultivar tended to yellowing with the reduction of soluble solids. Rama Forte and Giombo tended to reddening with increasing SS. The fruits of the Giombo cultivar had a higher SS/TA ratio, thus demonstrating that they are tastier compared to the other cultivars. The cultivars Giombo and Pomelo should be prioritized when choosing based on plant production, without worrying about shape and fruit color characteristics.
\end{abstract}

Keywords: Diospyros kaki L., production, fruit quality, total soluble solids.

\section{Introduction}

The persimmon is native to subtropical and temperate regions of the Asian continent. The persimmon fruit tree is deciduous and native to China, the first country to produce persimmon in the world (FAOSTAT, 2010). It was introduced in Brazil in the late nineteenth century, but expanded in the country only in 1920, with new techniques and cultivars brought by Japanese immigrants (Sato and Assumpção, 2002). Despite being produced traditionally in the Southeast and South of Brazil, areas of subtropical climates, persimmon crops are expanding to tropical regions of the country, such as in the middle São Francisco Valley (Lopes et al., 2014).

In places with tropical climate, such as Goiás and Northeastern Brazil, the cultivation occurs at elevations above $700 \mathrm{~m}$. In such sites, the induction of flowering may be carried out at any time of the year, which enables the production of fruits in the off season of other producing regions (Lopes et al., 2014).

The persimmon is a slow growing and deciduous plant that begins fruit production from the third year of life and progressively increases until the fifteenth year of life, when it stabilizes (Simão, 1998). An adult plant in a well-run orchard usually produces $100 \mathrm{~kg}$ to $150 \mathrm{~kg}$ of fruit per year, depending on the cultivar (IAC, 2000). Harvesting in subtropical climate is concentrated between the months of February and May, with the fruits being sold quickly due to the low post-harvest durability. This aspect causes an excessive increase in supply and falling prices in the harvest period (Blum et al., 2008). During the off season, the fruit is marketed at up to five times more than in the harvest period (Lopes et al., 2014).

Persimmon has significant amounts of pectin, starch, and has low-acid and total soluble sugar contents, ranging from $10.0 \%$ to $19.5 \%$ in tannic varieties, such as "Pomelo", "Giombo" and "Rama Forte" (Porfirio-da-Silva et al., 2011). In Brazil, the fruit is consumed preferably in natura, and may be industrialized and transformed into products such as persimmon vinegar and dried fruit (Cavalcante et al., 2007). The tannic varieties are harvested in the pre-climacteric stage and are submitted to an astringency removal procedure. (Edagi and Kluge, 2009). 
Physical and chemical characteristics of fruits of persimmon trees vary among cultivars, harvest season and fruit ripening stages (Cavalcante et al., 2007). During maturation, some changes occur that during maturation can be evaluated by physical and chemical methods and are used as parameters to monitor the maturation progress. The joint evaluation of parameters such as soluble solids contents, $\mathrm{pH}$, acidity and firmness, is used to identify the maturation stage of the fruit, and to follow the post-harvest ripening process (Blum et al. 2008). Therefore, the objective of this study was to quantify the production of three persimmon cultivars planted in Goiás, a tropical region with a dry season, and to characterize its fruits in respect to physical and chemical characteristics.

\section{Results and discussion}

The analysis of variance showed significant differences $(p<0.05)$ between persimmon cultivars studied for all parameters, thus suggesting that the characteristics vary among cultivars (Table 2). The persimmon yield per Giombo plant was higher than the recorded for the cultivar Rama Forte. The yield obtained with Pomelo cultivars was like that of the other two cultivars. Grellmann et al. (2003) worked with the cultivar Rama forte at Veranópolis - RS (temperate region) and reached an average production of $25.94 \mathrm{~kg}$ per plant, in eight harvests studied (plants from five to twelve years of age), resembling the results found in Anápolis (28.4 kg per plant). These results show that the cultivar produced the expected for the plant age, regardless of the site and planting time.

Peche (2016) studied the production of persimmon fruit (Pomelo cultivar) at Mantiqueira Mountains, SP during the 2014 and 2015 production cycles, and recorded a yield of $206.82 \mathrm{~kg}$ and $0.50 \mathrm{~kg}$ of fruit per plant. The values found in Anápolis differ from the others obtained in the literature. This is possibly due to the behavior of alternate production plants. Giombo cultivar reached a yield of $150 \mathrm{~kg}$ per plant in Campinas - SP, despite having provided the highest yield per plant $(67.8 \mathrm{~kg})$ (Martins and Pereira, 1989).

Cultivar Giombo is largely grown in southern Brazil and important because it is a late variety, harvested in May, escaping the period of greater supply (Blum et al. 2008). In this study, cultivar 'Giombo' produced on average the highest number of fruit per plant (545 fruit), and is considered the most productive among the three cultivars studied. These results indicate the possibility of commercially producing the Giombo persimmon elsewhere, such as in the state of Goiás, reducing expenses for transportation, storage and post-harvest losses.

Rama Forte and Pomelo presented no statistical differences on fruit per plant. Fruit production of the cultivar Rama Forte was resembled the reported by Grellmann et al. (2003) at Rio Grande do Sul, and Peche (2016) at São Paulo, both typical subtropical regions, indicating that the cultivar adapts to regions of tropical climates.

The cultivar Giombo exhibited the lowest mass in comparison with the others, despite the high number of fruit. This may be explained by Razzouk (2007), who states that, for the Giombo and Pomelo cultivars, the increased production of fruits per plant leads to smaller sized fruit. Fruit size directly influences the quality and value of the product. The larger the fruit, the more attractive it will be to the consumer and, consequently, more profitable will it be to the producer. Therefore, fruit thinning can be used in cultivating the Giombo cultivar, thus providing increased fruit size and crop yield.
Fruit thinning in apple trees improves fruit size and quality, and prevents production alternation by removing excessive fruit loads (Petri et al. 2013). The removal of the excess production in years with excessive fruit set results in larger and hence more valuable fruit. According to Moreira et al. (2011) management practices that provide the development of larger fruit and flowering in the following year, are essential to ensure high yields of the "Ponkan" tangerine. Peche (2016) obtained an average yield with Pomelo persimmon in the Mantiqueira Mountains of 1380 fruits per plant in 2014 and 3 fruits per plant in 2015. There is an alternating production in this cultivar as a natural trait (Ojima et al., 1985; Peche, 2016). In Anápolis a production of 228 fruit per plant was obtained. This may mean that the plants of the current study were at a production alternation period, leading to a higher percentage of fruit abortion. Alternating production can be controlled by severe winter pruning of the branches and early thinning of excess fruit, in the years in which abundant fruiting was expected Peche (2016).

The Cultivar Pomelo showed higher average fruit weight (224 g), when compared with Rama Forte and Giombo (Table 2). The average fruit mass obtained in Anapolis was different from previous records. Cavalcante (2007) studied five persimmon cultivars in Jaboticabal - SP (humid tropical climate with dry winter), and obtained an average weight of 124.6 $\mathrm{g}$ for Pomelo persimmon, 117.2 $\mathrm{g}$ for Giombo and 86.2 $\mathrm{g}$ for Rama Forte. In Anapolis, Pomelo and Rama Forte produced heavier fruits. This behavior is probably based on the climate conditions. Pomelo is a cultivar adapted to tropical climates (Razzouk, 2007)

Rama Forte exhibited satisfactory results regarding average fruit weight. The Rama Forte cultivar produces average fruit weight of $150 \mathrm{~g}$ in São Paulo (IAC, 2014). In addition, an average weight of $140.25 \mathrm{~g}$ has been recorded for Rama Forte in Rio Grande do Sul (Grellmann et al., 2003). The average fruit weight of the cultivar Pomelo in Anápolis was the largest in the literature. The Bulletin 200 (2014) states that the cultivar Pomelo in São Paulo has an average weight of $160 \mathrm{~g}$ per fruit. Peche (2016) found fruit with an average weight of $151 \mathrm{~g}$ in 2014 at Mantiqueira Mountains (SP), and Acquarone (2003) obtained fruit with $154 \mathrm{~g}$ in Jaboticabal SP. The Giombo cultivar produces fruit with about $140 \mathrm{~g}$ (Martins and Pereira, 1989; Boletim 200, 2014) and $94.5 \mathrm{~g}$ (Aquarone 2003). The weight found in Anapolis is within the pattern of the cultivar, despite the large number of fruits and the relationship between size and number of fruits. Therefore, thinning of the fruit set would increase weight, size and, consequently, the price of the fruit.

Plant spacing affects the final fruit size (Godoy and Cardoso, 2003). Pio et al. (2011) recommend larger spacing for tannic and variable varieties, for which plants are more vigorous. In the experiment (spacing of $7 \mathrm{~m} \mathrm{x} 5 \mathrm{~m}$ ) the number of fruits per plant and seeds per fruit certainly affected the final size and weight of the fruit. The yield per hectare of the Giombo cultivar, considering a spacing of $7 \mathrm{~m}$ x $5 \mathrm{~m}$, was statistically higher than of the cultivar Rama Forte, 19 and 8 tha $^{-1}$ of fruit, respectively. The production of the cultivar Pomelo (13.5 t.ha $\left.{ }^{-1}\right)$ was not statistically different from the other two $(\mathrm{P}>0.05)$. The yield per hectare of the Rama Forte cultivar in Anapolis (8.07 t.ha ${ }^{-1}$ ) was lower than the reported by other authors. Grellmann et al. (2003) reported an average yield of $12.969 \mathrm{~kg}^{-h^{-1}}(5.0 \mathrm{~m} \mathrm{x} 4.0 \mathrm{~m}$ spacing; 500 plants.ha $^{-1}$ ), considering plants of five to twelve years of age (Veranópolis - RS). In 2010, 2011 and 2012 (second to fourth year of plant life) the cultivar Rama Forte yielded 2.475 t.ha $a^{-1}, 6.262$ t.ha $^{-1}$ and 11.487 t.ha $^{-1}$, respectively in Petrolina - PE, a very hot semiarid region $(4.0$ 
m x 2.0 m spacing; 1,250 plants.ha ${ }^{-1}$ ) (Lopes et al., 2014). Based on these results, it can be assumed that the production of the cultivar would increase in a denser spacing. Peche (2016) studied adult Pomelo persimmon plants in the Mantiqueira Mountains, state of São Paulo and recorded a fruit productivity ranging from 0.2 t.ha $^{-1}$ to 84.80 t.ha $^{-1}$. The pomelo cultivar produced $13 \mathrm{t}^{-\mathrm{ha}^{-1}}$ in Anápolis. Despite the productivity being within the range of growth parameters, this value was lower than the recorded by other authors (Peche, 2016; Ojima et al, 1985). Note that the plants of the Anápolis Experimental Station are in adulthood and in full production (12 years). This may mean that the lack of fruit thinning negatively influenced final production. Further studies are needed to know the actual behavior of the cultivar in the region of interest. As expected, the Pomelo cultivar provided the largest (largest physical dimensions) and heaviest fruit when compared to other cultivars, regardless of the harvest season (Table 3). There was a significant interaction between the persimmon varieties and double interaction was observed between the factors (cultivar and time) and on the parameters (physical and chemical) of the evaluated fruit. Results show the variation of the characteristics among cultivars.

The size of the persimmon fruit is of great importance in Brazil, as it is consumed as fresh fruit (Cavalcante, 2007). The fruit collected in the first season were larger than those of the second (Table 3). Factors such as leaf area, plant spacing, the number of seeds in the fruit and the number of fruits on the plant may affect fruit size (Godoy and Cardoso, 2003). In this study, only the number of fruits on the plant was evaluated. The Giombo cultivar produced smaller fruit compared to other cultivars. This result was expected due to the large number of fruits produced by the plant. The increased production of fruit per plant causes fruit to be smaller in the Giombo and Pomelo cultivars (Razzouk, 2007). The Giombo cultivar showed higher growth in transverse than longitudinal diameter, in the two harvest seasons. The Transverse longitudinal diameter ratio $(\mathrm{H} / \varnothing)$ for this cultivar was on average 1.14, Providing the typical ovoid shape, as previously recorded (Martins and Pereira, 1989). The H/Ø ratio in the Pomelo cultivar was close to 0.93 meaning that these fruits have more rounded shape. The $H / \varnothing$ ratio value of 0.83 gives the fruit a more rounded-flattened shape than other cultivars. Cavalcante (2007), studied the persimmon fruit of the cultivars Rubi, Taubaté, Giombo, Rama Forte and Pomelo at Jaboticabal-SP and found statistical differences in terms of longitudinal diameter among Rubi, Taubaté and Giombo cultivars, all of which had higher diameters when compared with Pomelo and Rama Forte. Different behavior was found for the transverse diameter when Giombo and Pomelo showed values that were statistically similar and higher than that of other cultivars.

The fruits of Giombo and Pomelo cultivars showed higher soluble solids contents (SS) in the first harvest (190 days after pruning), $18.44{ }^{\circ}$ Brix and $18.77^{\circ}$ Brix, respectively, compared with the Rama Forte cultivar $\left(17.44^{\circ}\right.$ Brix) (Table 4). In the second harvest (220 days after pruning), the Pomelo cultivar showed lower value in comparison, whereas Rama Forte and Giombo provided similar results ( $p>0.05$ ).

The reduction of SS contents can be explained and assigned to processes that transform or degrade soluble solids (sugars, organic acids), such as cellular respiration and senescence. Over time the harvested fruit exhibit more accelerated degradative processes for several substances, including sugars present in the fruit pulp (Porfírio-da-Silva et al., 2011).
This may also have occurred due to the type of each cultivar, because the Pomelo cultivar belongs to a persimmon group that always has tannins in its composition, regardless of the presence of seeds. Rama Forte and Giombo belong to the variable group, where the presence of seeds affects the tannin contents (Campo-Dall'Orto et al., 1996). The variation was due to the harvest time, whereas, in the same fruit, the SS increases with maturity, by increasing the contents of simple sugar (Chitarra and Chitarra, 2005). The SS of the fruit are also affected by other factors, such as position of the fruit on the plant, light penetration in the canopy, type of branch and pruning (Comiotto et al., 2012). Soluble Solids contents ranges between $12.44^{\circ}$ Brix and $22.23^{\circ}$ Brix for Pomelo, $12^{\circ}$ Brix and $12.77^{\circ}$ Brix for Rama Forte and $12.06^{\circ}$ Brix and 22.26 ${ }^{\circ}$ Brix for Giombo (Acquarone, 2003; Cavalcante, 2007; Vieites et al., 2012). In this study, the cultivar Giombo, had fruits with about $19^{\circ}$ Brix. Higher values of Soluble Solids are of interest for the industries that process fruit into vinegar and dry fruit. Therefore, the Soluble Solids contents obtained in this study may be considered within the variation ranges reported in the literature.

The Titratable Acidity (TA) contents were statistically similar among the three cultivars of the study, but differed between the two harvest seasons. In the first season, the Titratable Acidity was about $0.09 \mathrm{~g}$ malic acid $100 \mathrm{~g}^{-1}$ and in the second $0.14 \mathrm{~g}$ of malic acid $100 \mathrm{~g}^{-1}$ for the three cultivars (Table 4). The reduction in acidity of the ripening fruit occurs due to consumption of acidic molecules, especially organic acids during the breathing process (Danieli et al., 2002; Blum et al., 2008) and malic acid is the predominant organic acid in the fruits (Porfirio-da-Silva et al., 2011). Nearly all the fruit harvested in the second harvest had higher acidity than in the first one, increasing from 0.09 to 0.14 . Fruit acidity can decrease or increase depending on the species, because organic acids are used in breathing for ATP production (adenosine triphosphate), causing a reduction in fruit acidity. In addition, the actual breathing process produces organic acids which can accumulate in the fruit, thereby causing slight increase in fruit acidity (Pimentel et al., 2010), which is what may have occurred with the persimmon fruit.

The Giombo cultivar exhibited the highest SS/TA ratio and was statistically different from the other cultivars evaluated in the first crop. This indicates that fruits of this variety have more pleasant taste than the others. In addition, the fruits of this cultivar take longer to reach the harvest point, a characteristic associated with the phenology of this plant variety. There was no significant difference of the SS/TA ratio among the three cultivars in the second crop. The only difference was between the two periods, showing that the fruits harvested at the beginning of the harvest period had more pleasant taste. Usually, the ratio increases during ripening due to the decrease in acidity, allowing a high ratio in fruits containing low soluble solids contents (Carvalho et al., 2011). However, the ratio decreased since acidity increased in the second harvest period.

Luminosity is a coordinate of the CIELAB color space that can range from 0 to 100 , in other words, from black to white (Lawless and Heymann, 1999). Statistical differences between the cultivars were observed when this parameter was analyzed (Table 5). The fruits of the cultivar Pomelo were lighter than the cultivar Giombo in the first harvest. The fruit of all cultivars were darker in the second harvest than the in 
Table 1. Chemical properties of the Oxisol before the pruning stage of the experiment (sample made on July 28, 2014) in two depths (0 to $20 \mathrm{~cm}$ and 20 to $40 \mathrm{~cm}$ ), in persimmon crops, Anápolis - GO, 2014.

\begin{tabular}{lllllllllll}
\hline Layer & $\mathrm{P}$ & $\mathrm{MO}$ & $\mathrm{pH}\left(\mathrm{CaCl}_{2}\right)$ & $\mathrm{K}$ & $\mathrm{Ca}$ & $\mathrm{Mg}$ & $\mathrm{H}+\mathrm{Al}$ & $\mathrm{Al}$ & $\mathrm{E}$ & $\mathrm{V}$ \\
\hline $0-20 \mathrm{~cm}$ & 5 & 27 & 5.6 & 164 & 5.5 & 2 & 2.2 & 0 & 10.12 & 78 \\
$20-40 \mathrm{~cm}$ & 1 & 20 & 5.0 & 140 & 3.3 & 1.1 & 2 & 0 & 6.76 & 70 \\
\hline
\end{tabular}

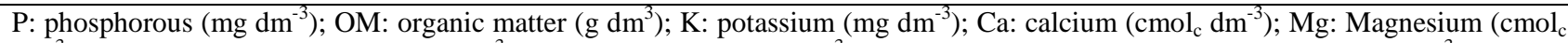
$\left.\mathrm{dm}^{-3}\right) ; \mathrm{H}+\mathrm{Al}$ : potential acidity $\left(\mathrm{cmol}_{\mathrm{c}} \mathrm{dm}^{-3}\right) ; \mathrm{Al}$ : Aluminum $\left(\mathrm{cmol}_{\mathrm{c}} \mathrm{dm}^{-3}\right)$; E: cation exchange capacity at pH $7.0\left(\mathrm{cmol}_{\mathrm{c}} \mathrm{dm}^{-3}\right) ; \mathrm{V}:$ base $^{-3}$ saturation $\left(\mathrm{cmol}_{\mathrm{c}} \mathrm{dm}^{-3}\right)$.

Table 2. Yield per plant $(\mathrm{kg})$, number of fruits per plant, average fruit weight $(\mathrm{g})$, and productivity of three persimmon cultivars planted in Anápolis - GO, crop 2014/2015.

\begin{tabular}{lllllllll}
\hline Cultivar & \multicolumn{2}{l}{ Yield per plant $(\mathrm{kg})$} & $\begin{array}{l}\text { Number of fruit per } \\
\text { plant }\end{array}$ & $\begin{array}{l}\text { Average } \\
\text { fruit }(\mathrm{g})\end{array}$ & $\begin{array}{l}\text { mass } \\
\left.\text { (t.ha }{ }^{-1}\right)\end{array}$ \\
\hline Rama Forte & 28.4 & $\mathrm{~b}$ & 214.3 & $\mathrm{~b}$ & 132.3 & $\mathrm{~b}$ & 8.07 & $\mathrm{~b}$ \\
$\begin{array}{l}\text { Giombo } \\
\text { Pomelo }\end{array}$ & 67.8 & $\mathrm{a}$ & 545.7 & $\mathrm{a}$ & 127.0 & $\mathrm{~b}$ & 19.37 & $\mathrm{a}$ \\
\hline V.C. $(\%)$ & 47.3 & $\mathrm{ab}$ & 227.5 & $\mathrm{~b}$ & 224.1 & $\mathrm{a}$ & 13.25 & $\mathrm{ab}$ \\
\hline $\begin{array}{l}\text { F-value } \\
\text { (C x E) }\end{array}$ & 24.4 & & 23.67 & & 2.43 & & 24.72 & \\
\hline
\end{tabular}

** significant at $1 \%$ probability. Means with the same letter in each column are statistically the same (Tukey p <0.01).

Table 3. Average values of longitudinal diameter, Transverse Diameter, and relationship between the Transverse Diameter and longitudinal diameter $(\mathrm{H} / \varnothing)$ of the fruit of three persimmon cultivars harvested in two periods in Anapolis - GO, during harvest 2014/2015.

\begin{tabular}{|c|c|c|c|c|c|c|c|c|c|c|c|c|}
\hline Factors & \multirow{2}{*}{\multicolumn{4}{|c|}{$\begin{array}{l}\text { Longitudinal Diameter }(\mathrm{mm}) \\
\text { Days after pruning }\end{array}$}} & \multirow{2}{*}{\multicolumn{4}{|c|}{$\begin{array}{l}\text { Transverse Diameter }(\mathrm{mm}) \\
\text { Days after pruning }\end{array}$}} & \multirow{2}{*}{\multicolumn{4}{|c|}{$\frac{\mathrm{H} / \varnothing \text { ratio }}{\text { Days after pruning }}$}} \\
\hline \multirow{2}{*}{ Cultivars } & & & & & & & & & & & & \\
\hline & 190 & & 220 & & 190 & & 220 & & 190 & & 220 & \\
\hline Rama Forte & 67.00 & $\mathrm{bA}$ & 55.85 & $\mathrm{bB}$ & 54.00 & $\mathrm{Ba}$ & 47.75 & $\mathrm{bB}$ & 0.804 & $\mathrm{bB}$ & 0.854 & $\mathrm{bA}$ \\
\hline Giombo & 55.25 & $\mathrm{cA}$ & 48.83 & $\mathrm{cB}$ & 60.5 & $\mathrm{bA}$ & 58.25 & $\mathrm{aA}$ & 1.094 & $\mathrm{aA}$ & 1.193 & $\mathrm{aA}$ \\
\hline Pomelo & 83.25 & $\mathrm{aA}$ & 66.3 & $\mathrm{aB}$ & 77.5 & $\mathrm{aA}$ & 61.5 & $\mathrm{aB}$ & 0.934 & $\mathrm{aB}$ & 0.928 & $\mathrm{aA}$ \\
\hline $\begin{array}{l}\text { F-value } \\
(\mathrm{C} \times \mathrm{x} E)\end{array}$ & 161.0 & & & & 29.703 & & & & 15 & & & \\
\hline
\end{tabular}

**significant at $1 \%$ probability. Means followed by the same letter are not statistically different from each other (uppercase on the line and lowercase the columns for each variable) by the Tukey Test at $5 \%$.

Table 4. Average values of soluble solids (SS), titratable acidity (TA), and of the SS/TA ratio in fruits for three persimmon cultivars harvested in two seasons (190 and 220 Days after pruning (DAP), in Anapolis - GO, during the harvest 2014/2015.

\begin{tabular}{|c|c|c|c|c|c|c|c|c|c|c|c|}
\hline \multirow{3}{*}{ Cultivars } & \multicolumn{3}{|c|}{ Soluble Solids $\left({ }^{\circ}\right.$ Brix $)$} & \multicolumn{4}{|c|}{ Titratable Acidity ( $\%$ malic acid) } & \multicolumn{4}{|c|}{ SS/TA Ratio } \\
\hline & \multicolumn{3}{|c|}{ Days after pruning } & \multicolumn{4}{|c|}{ Days after pruning } & \multicolumn{4}{|c|}{ Days after pruning } \\
\hline & 190 & 220 & & 190 & & 220 & & 190 & & 220 & \\
\hline Rama Forte & 17.44 & 19.22 & $\mathrm{aA}$ & 0.093 & $\mathrm{aB}$ & 0.139 & $\mathrm{aA}$ & 189.50 & $\mathrm{bA}$ & 140.55 & $\mathrm{aB}$ \\
\hline Giombo & 18.44 & 19.78 & $\mathrm{aA}$ & 0.084 & $\mathrm{aB}$ & 0.161 & $\mathrm{aA}$ & 219.75 & $\mathrm{aA}$ & 125.35 & $\mathrm{aB}$ \\
\hline Pomelo & 18.77 & 17.56 & $\mathrm{bB}$ & 0.097 & $\mathrm{aB}$ & 0.149 & $\mathrm{aA}$ & 193.00 & $\mathrm{bA}$ & 117.87 & $\mathrm{aB}$ \\
\hline F-value $(\mathrm{CxE})$ & $19.383 * *$ & & & 0.033 & & & & $4.642 *$ & & & \\
\hline
\end{tabular}

$* *$ significant at $1 \%$ probability; * significant at $5 \%$ probability. Means followed by the same letters are not statistically different from each other (uppercase on the line and lowercase the columns for each variable) by the Tukey Test at $5 \%$.

Table 5. Color determination values ( $\mathrm{L}^{*}$, chroma and Hue) for the three persimmon cultivars in two harvest seasons (190 and 220 days after pruning), in Anapolis during the harvest 2014/2015.

\begin{tabular}{|c|c|c|c|c|c|c|}
\hline \multirow{3}{*}{$\begin{array}{l}\text { Factors } \\
\text { Cultivars }\end{array}$} & \multirow{2}{*}{\multicolumn{2}{|c|}{$\begin{array}{l}L^{*} \\
\text { Days after pruning }\end{array}$}} & \multirow{2}{*}{\multicolumn{2}{|c|}{$\begin{array}{l}\text { Chroma } \\
\text { Days after pruning }\end{array}$}} & \multirow{2}{*}{\multicolumn{2}{|c|}{$\begin{array}{l}\text { Hue } \\
\text { Days after pruning }\end{array}$}} \\
\hline & & & & & & \\
\hline & 190 & 220 & 190 & 220 & 190 & 220 \\
\hline Rama Forte & $44.75 \mathrm{cA}$ & $31.82 \mathrm{bB}$ & $32.00 \mathrm{bA}$ & $25.50 \mathrm{bB}$ & $49.87 \mathrm{aA}$ & $39.64 \mathrm{bB}$ \\
\hline Giombo & $49.00 \mathrm{bA}$ & $35.17 \mathrm{bB}$ & $36.75 \mathrm{bA}$ & $29.25 \mathrm{bB}$ & $53.35 \mathrm{aA}$ & $42.39 \mathrm{bB}$ \\
\hline Pomelo & $54.75 \mathrm{aA}$ & $27.36 \mathrm{aB}$ & $45.75 \mathrm{aB}$ & $67.50 \mathrm{aA}$ & $55.05 \mathrm{aB}$ & $71.77 \mathrm{aA}$ \\
\hline
\end{tabular}

$* *$ significant at $1 \%$ probability. Means followed by the same letter are not statistically different from each other (uppercase in the line and lowercase in the columns) by the Tukey test at a $5 \%$ significance level. 
the first. The cultivar Pomelo had the lowest amount of light within the second harvest.

The Hue angle values indicate color tones, and thus show the tendency of the fruit being colored orange and red. Persimmon has the characteristic of accentuating the red color due to the maturation stage, which means that Hue angle values tend to decrease in fruit ripening (Silva et al., 2011). This color pattern was observed in the Rama Forte and Giombo cultivars, while the Pomelo showed an increase in the second harvest season, confirming luminosity results.

Giombo and Rama Forte have similar chroma values $(\mathrm{C} *)$ indicating paleness. In the case of the persimmon, the chroma values tend to increase with maturation. A lighter appearance may be due to the presence of waxes, which occurs naturally on the fruit and reduces water loss (Blum et al., 2008). The most vivid colors in the Pomelo cultivar may be due to lower amounts of waxes. The fruits were probably cleaner the first harvest than in the second.

Melo et al. (2015) characterized different varieties of tomato plants and showed that in deciding the best variety to be cultivated, productive, morphological and physical and chemical characteristics of the fruits should be evaluated together. Thus, the relationship between the parameters evaluated best highlights the characteristics of the varieties. The fruit evaluated showed slightly red and strongly orange color, with average brightness. These clearly show that the color is similar despite different cultivars being used, enabling the producer to choose the cultivars best suited to growing conditions without worrying about the fruit color parameters. This was the first study evaluating the phenology of persimmon in Goiás, and yet all cultivars showed good productivity levels and fruit quality. This justifies the inclusion of the culture as another exploration option for regional agribusiness, especially family agriculture. The persimmon has adapted well to Brazilian tropical conditions, and may be an alternative to the local agribusiness. Appropriate cultural practices should be evaluated for each cultivar, such as spacing, fertilization, time of production pruning, fruit thinning, use of plant growth regulators, etc. The plants evaluated received the same minimum treatment which could have influenced the production and characteristics of fruits. More detailed studies on the behavior of plants should be developed, especially on the use of new cultivars of economic importance to obtain more generalized answers on phenological and productive potential of the culture.

\section{Material and methods}

\section{Location and plant material}

The study was conducted with persimmon fruits (Diospyros $k a k i$ L.) (harvest 2014-2015). The physical and chemical analysis were carried out in the Laboratory of the Horticulture Sector of the Agronomy School of Federal University of Goiás (Universidade Federal de Goiás), Goiânia - GO. Fruits from three cultivars of the (Diospyros $k a k i$ L.) species of persimmon were obtained from twelveyear-old trees cultivated at the Rural Experimental Station of Anápolis - GO. The persimmon trees were planted at a spacing of $7 \mathrm{~m} \times 5 \mathrm{~m}$ and. Three varieties of scion were used: Rama Forte, Giombo and Pomelo.

The experimental site has approximately $1000 \mathrm{~m}$ of altitude. The average annual precipitation is $1465.5 \mathrm{~mm}$, mainly concentrated from December to March. From May to August a dry season occurs. According to Koeppen, the regional climate is tropical with a dry season. The temperature is cooler due to the high altitude, ranging from a minimum average of $18^{\circ} \mathrm{C}$ and maximum average of $28^{\circ} \mathrm{C}$ (Bonnet, 2003).

\section{Experimental conduction and experimental design}

Two assessments were conducted: one evaluating the production components of the three cultivars and the other assessing the physical and chemical characteristics of the fruits harvested in two seasons. The data on the number of fruits per plant and fruit weight of the persimmon, Rama Forte, Giombo and Pomelo cultivars were obtained from a completely randomized design with eight replications, composed of one plant per plot.

A completely randomized design was adopted for the physical and chemical evaluations of the fruit in a $3 \times 2$ factorial arrangement, corresponding to three persimmon cultivars (Pomelo, Rama Forte and Giombo) and two harvest seasons (190 days after pruning and 220 days after pruning). Two fruits per plant of four plots were considered, for a total of 48 analyzed fruits.

The plants received the recommended cultural practices (Martins and Pereira 1989). Plants were harvested with the fruit in pre-climacteric stage (ripening), when changing from green to yellow-orange color, due to the degradation of chlorophyll and/or synthesis of other pigments (Chitarra and Chitarra, 2005). The harvested fruit were stored in the Laboratory of the Horticulture Sector of the Agronomy School of Federal University of Goiás for subsequent astringency treatment.

The persimmon fruits were treated with ethanol for astringency at a concentration of $3.5 \mathrm{ml}$ of alcohol per fruit $\mathrm{kg}$ in closed chambers for four days, as recommended by Terra et al. (2006). Astringency was removed from the fruit after four days, in an average temperature of $22{ }^{\circ} \mathrm{C}$ and $90 \%$ relative humidity. Physical and chemical analyzes were performed when the fruits were in the ideal condition for fresh consumption.

\section{Physical analysis}

The transverse and longitudinal diameter of the fruits were measured using a digital caliper (Starfer, Digital Vernier Caliper IVEO-150mm). The Transverse Diameter was measured from the apex of the fruit peduncle, and the longitudinal diameter was measured in the equatorial fruit line. The results were expressed in millimeters $(\mathrm{mm})$. The average fruit weight was evaluated, weighing the fruits individually in a digital electronic analytical balance, and the results were expressed in grams $(\mathrm{g})$.

\section{Production}

The production per plant and productivity were evaluated to determine yield. The average production per plant was calculated in $\mathrm{kg}$ and productivity of the area in $\mathrm{t} \mathrm{ha}^{-1}$. The production plant was estimated by multiplying the number of fruits per plant by the average fruit weight (in $\mathrm{kg}$ ), and the data were expressed as kg.plant- ${ }^{1}$. The yield per hectare was estimated by multiplying the yield per plant $(\mathrm{kg})$ by the number of plants per hectare ( 285 plats, spaced $7 \mathrm{~m} \mathrm{x} 5 \mathrm{~m}$ ), and dividing by 1.000. Results were expressed in tons per hectare $\left(\right.$ t.ha $\left.^{-1}\right)$. The color of the peel of all fruits was determined by reading three parameters defined by the CIELAB system. The color parameters $\left(L^{*}, a^{*}, b^{*}\right)$ were determined by Hunterlab colorimeter, model ColorQuest II 
Sphere, Geometric optical sensor ball, performing reading by reflection, with a $10^{\circ}$ viewing angle, main illuminant D65 and excluded specular reflection (RSEN). The Chroma $\left(\mathrm{C}^{*}\right)$ and ${ }^{\circ} \mathrm{Hue}$ of the samples were established from the CIELAB system parameters, through Equations 1 and 2:

Equation 1: $C^{*}=\sqrt{\left(a^{*}\right)^{2}+\left(b^{*}\right)^{2}}$

Equation 2: Hue=arctg $(b * a *)$, where $a *>0 ; b *>0$

\section{Chemical analysis}

Fruit quality was evaluated through soluble solids contents (SS, expressed in ${ }^{\circ}$ Brix), titratable acidity (TA, expressed in \% malic acid), $\mathrm{pH}$, and SS/TA ratio. Two fruit were evaluated per replicate, in two harvest seasons, one at the beginning (190 days after pruning).) and one later (220 days after pruning).

The total soluble solids contents were determined by Reading the Brix degrees of the sample at $20^{\circ} \mathrm{C}$. A digital refractometer (Atago N-1E) was used, according to the method proposed by the Association of Official Analytical Chemists (AOAC, 2010). The titratable acidity was determined by titration with a sodium hydroxide solution $(\mathrm{NaOH}) 0.01 \mathrm{~N}$, using $1 \%$ phenolphthalein as an indicator, also following AOAC (2010). The result was expressed in percentage of malic acid. The SS/TA ratio is the ratio of soluble solids (SS) and titratable acidity (TA) (Melo et al., 2015).

\section{Data analysis}

An analysis of variance and Tukey test $(p<0.05)$ were performed to compare the effect of different cultivars, the harvest time and the effect of both. Analyses were carried out using the software "SISVAR".

\section{Conclusion}

The cultivars had good productivity levels, especially the Pomelo and Giombo cultivars. Giombo was the most productive in the region with an average yield of 545 fruit per plant, but the fruit were lighter (reduced mass of $127 \mathrm{~g}$ ), small and less attractive, which could be negative for the producer who may charge more for larger fruit. The Pomelo fruit has the highest average weight (224 g). It does not stand out with maximum yield, but better serves the consumer market thanks to fruit attractiveness. Giombo and Pomelo had the highest yields (13.25 and 19.27 ton/ha). The yield obtained with Rama Forte was lower when compared with other results in the literature. However, Rama Forte is a costeffective alternative for being the most commercialized cultivar in the country. Harvest time affects fruit parameters. The fruit harvested 190 days after pruning exhibited higher SS contents and lower acidity when compared with the other fruit harvested 220 days after pruning, regardless of the cultivar. The fruits on the plant darken over time. The Pomelo cultivar tended to yellowing with the reduction of soluble solids. Rama Forte and Giombo tended to reddening with increasing SS. The fruits of the Giombo cultivar had a higher SS/TA ratio, indicating that they are tastier than the other cultivars. The persimmon cultivars Rama Forte, Giombo and Pomelo cannot be discriminated by the shape of its fruit. All the fruit evaluated maintained the typical shape and coloration inherent to the corresponding cultivar. The Giombo and pomelo cultivars should be a priority when choosing, based on plant production, without worrying about the shape and fruit color characteristics.

\section{Acknowledgment}

The authors thank the Brazilian National Council for Research (CNPq) for the master's scholarship granted to the first author. We also thank the Graduate Program in Agronomy of the Federal University of Goiás for academic support and the Rural experimental station of Anápolis of the Agency for Technical Assistance, Rural Extension and Agricultural Research of the state of Goiás- EMATER for the area and availability for research.

\section{References}

Acquarone SM (1999) Caracterização físicoquímica de frutos de caquizeiro (Diospyros kaki L.) nas condições de Jaboticabal-SP. Jaboticabal. 36f. Tese - Faculdade de Ciências Agrárias e Veterinárias, Universidade Estadual Paulista.

AOAC (2010) Association Official Analytical Chemists. Official Methods of Analysis of AOAC International. 18th ed., 3, Gaithersburg: AOAC.

Blum J, Hoffmann FB, Ayub RA, Prado PVB, Malgarim MB (2008) Destanização do caqui 'Giombo' com etanol e ethephon. R Ceres. 5(1): 54-59.

Bonnet WW (2003) Gestão ambiental de áreas de aeronáutica, o caso da Base Aérea de Anápolis, GO. Dissertação (Mestrado em Planejamento e Gestão Ambiental) Universidade Católica de Brasília.

Campo-Dall'orto FA, Ojima M, Barbosa W, Zullo MAT (1996) Novo processo de avaliação da adstringência dos frutos no melhoramento do caquizeiro. Bragan. 55(2): 273 243.

Carvalho AV, Cavalcante MA, Santana CL, Alves RM (2011) Características físicas, químicas e atividade antioxidante de frutos de matrizes de cajazeira no estado do Pará. Alim Nutr. 22(1): 45-53.

Cavalcante IHL, Martins ABG, Oliveira IVM, Beckmann MZ (2007) Características de frutos de cinco variedades de caqui madurados en la planta o en post cosecha. R Biol Ciên Ter. 7(2).

Chitarra MIF, Chitarra, AB (2005) Pós colheita de frutos e hortaliças: fisiologia e manuseio. Lavras: ESAL/FAEPE. $787 \mathrm{p}$.

Comiotto A, Fachinello JC, Hoffmann A, Machado NP, Galarça SP, Betemps DL (2012) Vigor, floração, produção e qualidade de pêssegos 'Chimarrita' e 'Maciel' em função de diferentes porta-enxertos. Ciên Rur. 42(5): 788-794.

Danieli R, Girardi CL, Parussolo A, Ferri VC, Rombaldi CV (2002) Efeito da aplicação de ácido giberélico e cloreto de cálcio no retardamento da colheita e na conservabilidade de caqui, Fuyu. R Bras Fruticult. 24 (1): 044-48.

Edagi FK, Kluge RA (2009). Remoção de adstringência de caqui: um enfoque bioquímico, fisiológico e tecnológico. Ciên Rur. 39(2): 585-594.

FAOSTAT (2010) Food and Agriculture Organization of the United Nations Statistics Division. Acess in: http://faostat3.fao.org/home/

Godoy AR, Cardoso AII (2003). Curva de crescimento e qualidade de frutos do melão rendilhado sob cultivo protegido. R Cer.50(289): 303-314.

Grellmann EO, Simonetto PR, Fioravanço JC (2003). Comportamento fenológico e produtivo de cinco cultivares e uma seleção de caquizeiro em Veranópolis, Rio Grande do Sul, Brasil. Pesq Agrop Gaú. 9(1-2): 71-76.

Lawless HT, Heymann H (1999) Sensory evaluation of food. Maryland: Aspen Pulishers. 
Lopes PRC, Oliveira IVM, Oliveira JEM, ASSIS JS (2014) Cultivo do Caquizeiro no Vale do São Francisco. Embrapa Semiárido. Circular Técnica, 107. 10 p. Petrolina.

Martins FP, Pereira FM (1989) Cultura do caquizeiro. São Paulo: Funep. 71 p

Melo APC, Fernandes PM, Venturoli F, Silva-Neto, CM, Rubio-Neto A (2015) Morphoagronomic Characterization of Tomato Plants and Fruit: A Multivariate Approach. Advan Agric. (2015): 1-6.

Moreira RA, Moreira RCA, Ramos JDR, Silva FOR (2011) Regularidade da produção de tangerineiras ponkan submetidas ao raleio químico bianual. R Bras Frut. 235-240

Ojima M, Dall'orto FAC, Barbosa W, Tombolato AFC, Rigitano O (1985). Frutificação alternada em caqui cultivar Pomelo (IAC 6-22). Brag. 44(1): 481-486.

Peche PM (2016) Production and fruit processing of persimmon, genetic diversity and propagation of cultivar in subtropical areas. 2016. 132 p. Tese (Doutorado em Agronomia/Fitotecnia) - Universidade Federal de Lavras.

Petri JL, Hawerroth FJ, Leite GB, Couto M (2013) Raleio químico em macieiras ‘fuji suprema' e 'lisgala' R Bras Frut. 35(1): 170-182.

Pimentel RMA, Guimarães FN, Santos VM, Resende JCF (2010) Qualidade pós-colheita dos genótipos de banana PA42-44 e prata-anã cultivados no norte de Minas Gerais. R Bras Frut. 32(2): 407-412.
Pio R, Scarpare-Filho JÁ, Mourão-Filho FAA (2011). A cultura do caquizeiro. Piracicaba: Esalq. Produtor Rural, 23 , $35 \mathrm{p}$

Porfírio-da-Silva LC, Almeida MM, Borsato AV, Raupp DS (2011) Qualidade pós-colheita do caqui 'Fuyu' tratado com a promalina. Acta Scientiarum. Agronomy, 33(3): 519-526.

Razzouk PLG (2007). Avaliação fenológica de dez variedades de caquizeiro Diospyros kaki L. e propagação por estaquia em regiões tropicais. 103 f. Dissertação (mestrado) - Universidade Estadual Paulista, Faculdade de Engenharia de Ilha Solteira.

Sato GS, Assumpção R (2002) Mapeamento e análise da produção do caqui no Estado de São Paulo. Inform Econ. 32(6): 47-54

Silva MC, Atarassi ME, Ferreira MD, Mosca MA (2011) Qualidade pós-colheita de caqui 'fuyu' com utilização de diferentes concentrações de cobertura comestível. Ciên Agrotecn. 35(1): 144-151.

Simão S (1998) Tratado de fruticultura. Piracicaba: FEALQ, $760 \mathrm{p}$.

Terra, FAM (2006) Destanização de caquis cv. Giombo em diferentes temperaturas e tempos de exposição. In: SIICUSP - Simpósio Internacional De Iniciação Científica Da USP, 14., 2006, Piracicaba, SP. Anais. Piracicaba, SP. Vieites, RL (2012) Caqui. Rev. Bras. Frutic. 34(3). 